\title{
Research Advances of Chemical Treatment of Wastewater with Low Concentration of Uranium
}

\author{
YU WenChao ${ }^{1,2, a}$, GUO Yadan ${ }^{1,2, b, \star}$, GAO Bai ${ }^{2, c}$, LIANG Ping ${ }^{2, d}$ \\ ${ }^{1}$ State Key Laboratory Breeding Base of Nuclear Resources and Environment, East China \\ University of Technology, Nanchang, Jiang Xi, China, 330013 \\ ${ }^{2}$ School of Water Resources \& Environmental Engineering, East China University of Technology, \\ Nanchang, Jiang Xi, China, 330013 \\ ayuwenchao2866@163.com, bguoyadan88@163.com*, 'gaobai@ecit.cn, ${ }^{\mathrm{d}} 1308257779 @ q q . c o m *$
}

Keywords: uranium wastewater; chemical method; zero-valent iron

\begin{abstract}
The article briefly introduces the harm of the uranium and the existence form of uranium in aqueous solution. Reviewing the research advances in recent years of chemical treatment of wastewater with low concentration of uranium, the article analyzes the main principle and advantages and disadvantages of the research advances of chemical treatment of wastewater with low concentration of uranium. It also puts forward some opinions on the further research directions.
\end{abstract}

\section{Introduction}

In recent years, with the rise of nuclear power, large-scale development of nuclear power plant, nuclear power as a clean, efficient, and green energy had been accepted by people. In the next 25 years, 100 300 nuclear power plants will be built around the world [1]. As an important nuclear fuel, the demand of uranium will increase day by day, but in the course of its processing, also brought the treatment and discharge problems of uranium-bearing wastewater. According to the IASA recommended, the low solubility of uranium-containing wastewater refers to the radioactivity concentration in the range of $37-3.7 \times 10^{5} \mathrm{~Bq} / \mathrm{L}$, and the wastewater mainly contain uranium, thorium, radium and other radioactive elements and heavy metals etc. The United States Environmental Protection Agency (EPA) regulations of the uranium mass concentration standard in the emission waste water of uranium mining and uranium processing is $30 \mu \mathrm{g} / \mathrm{L}$; Canada suggests the emission standard for $20 \mu \mathrm{g} / \mathrm{L}$; The emission standards of China is $50 \mu \mathrm{g} / \mathrm{L}$; The recommended value of World Health Organization is $2 \mu \mathrm{g} / \mathrm{L}[2]$.

The traditional treatment methods of low solubility of uranium wastewater contain chemical precipitation, ion exchange method, evaporation concentration method, adsorption method, etc. Chemical methods for removing uranium is simple, low cost, high rate of removal uranium, and the latest research progress of chemical treatment of low solubility of uranium wastewater were briefly introduced in the article.

\section{The form of uranium in uranium wastewater and the harm to ecology}

The valence state of uranium in aqueous solution is trivalent, tetravalent, pentavalent and sexivalent. Trivalent and tetravalent uranium are easily oxidized to hexavalent, pentavalent uranium susceptible to disproportionation reactions in acidic solutions, and reduced to tetravalent and oxidized to hexavalent. Uranium in wastewater is generally in the presence of hexavalent form $\left(\mathrm{UO}_{2}{ }^{2+}\right)$, when $\mathrm{pH}>3, \mathrm{UO}_{2}{ }^{2+}$ ion hydrolysis for $\mathrm{UO}_{2}(\mathrm{OH})^{+},\left(\mathrm{UO}_{2}\right)_{2}(\mathrm{OH})_{2}{ }^{2+}$ and $\left(\mathrm{UO}_{2}\right)_{3}(\mathrm{OH})_{5}{ }^{2+}$; when $\mathrm{pH}=5 \sim 6$ can be precipitated completely [3].

Improper disposal of wastewater containing uranium will spread into the soil and leach into the ground water, or air pollution caused by wind erosion of soils, and endangers the ecological environment and human. Uranium can be not only their own weak decay release beta ray and gamma ray, external exposure pathways of radiation damage to the biological and human body. But also uranium can enter the body through the respiratory tract and digestive system to cause internal 
radiation damage, which can harm the human kidneys, immune system, and nervous system. In addition, the chemical toxicity of uranium is the largest for animal and human kidney damage, which may lead to kidney failure.

\section{Chemical treatment of low solubility of uranium wastewater}

Chemical methods is one of the methods to remove U(VI) in recent years, mainly including chemical precipitation, adsorption, ion exchange method, liquid emulsion membrane separation and zero-valent iron reduction process.

\section{Chemical precipitation method.}

Chemical precipitation usually use some flocculants (such as $\mathrm{CaO}$, and $\mathrm{Mg}(\mathrm{OH})_{2}$, iron salts, etc. ), coagulant aid (such as clay, activated $\mathrm{SiO}_{2}$ and polymeric electrolytes, etc.) and the solution of the uranium in produce the physical chemistry such as Bridges, the electric adsorption and role of coagulation sedimentation and separation, and purification of uranium Precipitation particles can combine with the suspended solids in the water for loose particles. So that the radionuclides can be adsorbed in water.

Most commonly used in chemical precipitation for lime precipitation, when $\mathrm{pH}=6 \sim 8$, some main harmful substances in the wastewater cannot meet emission requirements. $\mathrm{PH}=10 \sim 11$, in addition to calcium and $\mathrm{SO}_{4}{ }^{2-}$, most of the harmful substances can meet emission requirements. The method commonly used to initially process wastewater or tailings pulp and recovery after the treatment of mine effluents. Heavy metal ions in waste water react with the hydroxyl ions generates insoluble hydroxides precipitates and co-precipitation with carrier role, separated uranium from the solution.

In recent years, some experts have proposed some not the commonly used method, achieved remarkable results. Such as Luo Mingbiao et al [4] reported the powdered magnesium hydroxide and dolomite as raw materials containing radioactive uranium with magnesium hydroxide preparation of emulsion waste water conditions, test results show that under the optimal conditions, the uranium content in waste water by dropped to below $0.05 \mathrm{mg} / \mathrm{L}$, and $\mathrm{pH}$ value control between $6 \sim 9$, meet the national environmental requirements. Su Kaizhou et al [5] found that wastewater treatment by "removal of hydrofluoric acid - lime neutralization adjustable pH- three levels of extraction ", according to the recommended procedure technical indicators to make uranium and thorium reached open water control standards.

\section{Adsorption method.}

Mechanism of adsorption of uranium in the process of purification of the waste water mainly include: ion exchange, surface recombination, surface precipitation and surface precipitation reduction, etc. [6]. Commonly used adsorbent is activated carbon, zeolite, kaolin, bentonite, clay, etc. It is a hot research topic to improve the adsorption efficiency of the traditional adsorbent modified or synthetic new adsorbent. Zhang etc. [7] found that in the process of the synthetic ball charcoal CSs while the water thermal response, filtering, washing and drying, reduce the drying temperature, prolong the drying time, so that the surface of the ball to produce a large number of carboxyl, improve the U(VI) adsorption capacity of the solution. Some organic compounds have strong functional groups with the ability of uranium coordination, and are often used as modifiers for clay minerals. The results of Wang etc. [8] research show that, the adsorption capacity of U(VI) was increased from $65.02 \mathrm{mg} / \mathrm{g}$ to 106.38 by HDTMA modified bentonite, when U(VI) initial concentration of $10 \mathrm{mg} / \mathrm{l}, \mathrm{pH}$ Value of 6 , sorbent dosage is $1.5 \mathrm{~g} / \mathrm{l}$, purification efficiency close to $100 \%$.

Magnetic modification not only can increase the specific surface area of the adsorbent, but also can be achieved by magnetic field to achieve solid-liquid separation after adsorption. Fan et al.[9] using coprecipitation method, magnetic iron oxide was covalently bonded to the surface of the attapulgite, attapulgite surface area from $110 \mathrm{~m}^{2} / \mathrm{g}$ increased to $135 \mathrm{~m}^{2} / \mathrm{g}$, to deal with $\mathrm{pH}$ value of 6.0 , the initial concentration of U(VI) solution of $4.76 \mathrm{mg} / \mathrm{l}$, efficiency is more than $99 \%$, sorbent dosage is $0.3 \mathrm{~g} / \mathrm{l}$. Composite particle of attapulgite and magnetic iron oxide is not only high 
adsorption efficiency, but also can complete the solid-liquid separation by magnetic field, which has the advantages of simple operation, low energy consumption and so on.

\section{Ion-exchange method.}

Ion exchange treatment of uranium-containing wastewater which can exchange uranium ion in waste water on the ion exchanger by exchangeable ions on the ion exchanger, has reached the purpose of purifying the uranium-containing wastewater. The method is simple in equipment, strong operability, and high removal efficiency, more suitable for low salt content and less suspended solids content of the system. When the concentration of competing ions in wastewater is high, competing ions may be exchanged on the ion exchanger to affect the uranium removal, generally believed that constant competition ion concentration $<1000 \sim 1500 \mathrm{mg} / \mathrm{L}$ is suitable for using ion-exchange treatment of radioactive wastewater treatment.

\section{Liquid emulsion membrane separation.}

Separation of the emulsion liquid membrane method is a new separation technology; the process is simultaneously on both sides of the membrane extraction and back extraction. Because of the limitation of physical chemical equilibrium extraction of uranium can against a concentration gradient transfer, so the efficiency of extraction is unmatched by solvent extraction. Kulkarni [10-11] by the method of emulsion film, the experimental research of uranium extraction, emulsion film, made of composite components which can be 6 times uranium enrichment. For the initial concentration of $600 \mathrm{~m} \mathrm{~g} / \mathrm{L}$ of uranium waste water, after two counter-current extractions, the uranium ions on the extraction content of residual liquid is lower than $50 \mathrm{mg} / \mathrm{L}$.

\section{Method of zero-valent iron reduction.}

As early as 1970 s, the zero-valent iron materials used in the treatment of organic wastewater, since 1990s, foreign experts began to study using these materials to deal with uranium-containing wastewater; the study of the removal mechanism and related processes in the past ten years has achieved great progress.

(1) Reduction mechanism of precipitation

Zero-valent iron is a strong reducing agent, on the electrochemical corrosion products, through the electronic transfer of zero-valent iron directly on the surface of $\mathrm{UO}_{2}{ }^{2+}$ reduction occurs. When the system contains adequate amounts of zero-valent iron and corrosion products $\left(\mathrm{Fe}(\mathrm{OH})_{3}\right)_{\text {not }}$ much, $\mathrm{UO}_{2}{ }^{2+}$ mainly is reduced to $\mathrm{U}(\mathrm{IV})$ and the iron is precipitated on the surface. The main reaction is:

$$
\begin{aligned}
& \mathrm{Fe}^{0} \stackrel{ }{\longrightarrow} \mathrm{Fe}^{2+}+2 \mathrm{e}^{-} \\
& \mathrm{UO}_{2}{ }^{2+}+4 \mathrm{H}^{+}+2 \mathrm{e}^{-} \longrightarrow \mathrm{U}(\mathrm{IV})+2 \mathrm{H}_{2} \mathrm{O}
\end{aligned}
$$

Abdelouas and others [12] study on the feasibility of reducing hexavalent uranium using zero-valent iron $\left(\mathrm{Fe}^{0}\right)$. Under temperature 24 degrees, they used iron filings and U(VI) mass concentration of 0.25 and $9.3 \mathrm{mg} / 1$ of solution were a series of tests. Solution $\mathrm{pH}$ value is 2 9 between. As in any study of $\mathrm{pH}$ value, within the time frame of a few hours to a few days, all uranium is removed completely. Restored the uranium formed a very low crystallinity hydrated uranium oxide $\left(\mathrm{UO}_{2} \bullet \mathrm{nH}_{2} \mathrm{O}\right.$ ). Main mechanism for removal of uranium from a solution found U(VI) reduced to $\mathrm{U}(\mathrm{VI})$, the reaction is:

$\mathrm{Fe}^{0}+\mathrm{UO}_{2}{ }^{2+}=\mathrm{Fe}^{2+}+\mathrm{UO}_{2}$

In order to study the removal efficiency of uranium in waste water by zero valent iron, $\mathrm{Gu}$ et al[13] had removal of uranyl ions from aqueous solution $\left(\mathrm{UO}_{2}{ }^{2+}\right)$ test, found more effective than iron adsorption material. In the initial concentration of up to $18 \mathrm{~g} / \mathrm{L}$ of uranium bearing solution, almost $100 \%$ of uranium can be removed by reaction with zero value of iron.

(2) Mechanism of adsorption removal

Under acidic conditions, zero-valent iron treatment of uranium-containing wastewater will produce large amounts of ferrous and ferric iron. And hydrolysis reaction, hydrolysis of Flocculent $\mathrm{Fe}(\mathrm{OH})_{2}$ and $\mathrm{Fe}(\mathrm{OH})_{3}$ precipitate by adsorption, flocculation in wastewater such as $\mathrm{U}(\mathrm{VI})$. Yan etc. [14] using nano-scale zero-valent iron in the anaerobic system restore to remove U(VI), when $\mathrm{U}(\mathrm{VI})$ concentration of $47.6 \mathrm{mg} / \mathrm{l}, \mathrm{pH}$ value of 6.92 , amount of adsorbent for $27.57 \mathrm{mg} / \mathrm{L}$, removal rate of $98.4 \%$. 
(3) The mechanism of micro-electrolysis

The potential iron is low, so it easy to form in the water corrosion cell. At this time it act as the anode and the impurity in the iron carbon act as cathode. The hydrogen ions in the cathode reduction reaction generate hydrogen separation, raising the reactor effluent $\mathrm{PH}$. The heavy metal ions in the cathode reduction reaction generate metal elemental by adsorption or intercept in the reactor. The anode oxidizing reaction of iron in the coagulation effect generate in the $\mathrm{Fe}^{2+}$ and $\mathrm{Fe}^{3+}$, the coagulation effect to be able to continue.

(4) Nano-scale zero-valent iron treatment of wastewater

Iron nanoparticles, referred to as "INP, because has more superior performance than zero-valent iron, is widely attention. INP the mechanism of pollutants removal mainly depends on the nature of the pollutants, but mainly by zero-valent iron oxide reduction.[15] For the reduction of chlorinated organic main is to be reduced to harmless, but for the heavy metal pollutants in the water, mainly through the adsorption effect of iron or reduction and degradation. Related studies have shown that INP than ordinary zero-valent iron treatment effect and speed are superior [16-17].

\section{Conclusion and prospect}

Currently these chemical method comparatively mature, but there are still many problems, such as chemical precipitation of sludge quantity is too large to cause secondary pollution, the limitations of using water, etc.; Adsorption method is expensive, large amount of wastewater is not applicable when; Ion exchange method, high cost, can only handle nuclide is ion mode, the alkaline wastewater; Emulsion membrane is expensive, are still in the experimental stages; Zero-valent iron reduction method with high efficiency, low cost, simple process, can be automatically run for a long time, and many other advantages, thus in the field of uranium waste water treatment by the people's increasing attention and favor. Reducing precipitation is a highly toxic U(VI) into the low toxicity U(IV) the most ideal way, thus can improve the reducing power of zero-valent iron. In addition, compared with zero-valent iron in the solution U(VI) removal effect of study, the adsorption in the solid phase material environment of U(VI) removal effect, few studies and adsorption in the solid phase material of U(VI) concentration in liquid phase concentration is much higher [18-19], so it is necessary to strengthen the zero-valent iron on the adsorption in the solid phase material environment mechanism research of $\mathrm{U}(\mathrm{VI})$.

\section{Acknowledgments}

This work was supported by the National Natural Science Foundation of China (21407022, 41162007, 41362011).

\section{References}

[1] ZHANG Haiqing. Survey of world uranium resources [J]. World Nuclear Geoscience, 2007, 4(24):213-215.

[2] Wang J S,Bao Z L,Chen S G,et al. Removal of uranium from aqueous solution by chitosan and ferrous ions $[\mathrm{J}]$. Journal of Engineering for Gas Turbines and Power-Transactions of The Asme,2011,133 (0845028).

[3] WEI Guangzhi, XU Lechang. Treatment technology of low concentration uranium-bearing wastewater and its research progress [J]. Uranium Mining and Metallurgy, 2007, 2(26):90.

[4] LUO Mingbiao, LIU Shujuan, YU Henghua. Treatment of the radioactive wastewater bearing uranium with magnesium hydroxide [J]. Technology of water treatment, 2002, 5(28): 274-277.

[5] SU Kaizhou, TANG Zhijun. Study on Treatment of Waste Water with U 8c Th [J]. HUNAN nonferrous metals, 1999, 5(15): 18-22. 
[6] Fan Q H,Li P,Chen Y F,et al. Preparation and application of attapulgite/iron oxide magnetic composites for the removal of $\mathrm{U}$ (VI) from aqueous solution [J]. Journal of Hazardous Materials,2011, 192(3):1851-1858.

[7] Zhang Z B,Nie W B,Li Q,et al. Removal of uranium (VI) from aqueous solutions by carboxylrich hydrothermal carbonspheres through low-temperature heat treatment in air [J]. Journal of Radioanalytical and Nuclear Chemistry,2013, 298(6):361-365.

[8] Wang Y Q,Zhang Z B,Li Q,et al. Adsorption of uranium from aqueous solution using hdtma $(+)$ — pillared bentonite:isotherm, kinetic and thermodynamic aspects [J]. Journal of Radioanalytical and Nuclear Chemistry,2012,293 (1) :231-239.

[9] Fan Q H,Li P,Chen Y F,et al. Preparation and application of attapulgite/iron oxide magnetic composites for the removal of U (VI) from aqueous solution [J]. Journal of Hazardous Materials,2011,192 (3) :1851-1859.

[10] Kulkarni PS. Recovery of uranium(VI) from acidic wastes using tri-n-octylphosphine oxide and sodium cabnate based liquid membranes[ J] .Chemical Engineering Journal , 2003, 92( 1 -3) : $209-214$

[11] Kulkarni PS, Mukhopadhyay S, Bellary MP, et al. Studies on membrane stability and recovery of uranium (VI) from aqueous solutions using a liquid emulsion membrane process [J]. Hydro metallurgy, 2002, 64(1): 49 -58.

[12] Abdelouas Abdesselam, Lutze Werner, Nuttall Eric, et al .Remediation of U(VI)-contaminated water using zero-valent iron [ J] .Earth \&Planetary Sciences , 1999, 328 : 315 -319 .

[13] G u B , Liang L , Dickey M J , et al. Reductive precipitation of uranium ( VI )by zero-valent iron[ J] .Environmental Science \& Technology , 1998 , 32 (21) :3366 -3373 .

[14] Yan S, Hua B, Bao Z Y, et al. Uranium (VI) removal by nanoscale zero-valent iron in anoxic batch systems [J]. Environmental Science \& Technology,2010,44 (20):7783-7789.

[15] Miehr R, Tratnyek P G, Bandstra J Z, et al. Diversity of contaminant reduction reactions by Zero-valent iron: Role of the reductate [J]. Environmental science \& technology, 2004, 38(1):139-147.

[16] Lien H L, Zhang W. Transformation of chlorinated methanes by nanoscale iron particles [J]. Journal of Environmental Engineering, 1999, 125(11):1042-1047.

[17] Lien H L, Zhang W. Nanoscale iron particles for complete reduction of chlorinated ethenes [J].Colloids and Surfaces A: Physicochemical and Engineering Aspects, 2001, 191(1-2):97-105.

[18] Liu C X, Jeon B H,Zachara J M, et al. Influence of Calcium on Microbial Rreduction of Solid Phase Uranium(VI). Biotechnol Bioeng, 2007, 97:1415-1422.

[19] Liu C X, Jeon B H,Zachara J M, et al. Kinetics of Microbial Reduction of Solid Phase U(VI) [J]. Environ Sci Technol,2006,40: 6290-6296. 